\title{
Criteria for Assessing Student Satisfaction with Online Courses
}

\author{
Terri Rothman, Lynn Romeo, Mary Brennan, Donna Mitchell \\ Monmouth University, USA
}

\begin{abstract}
The first purpose of this study was to examine the reliability and validity of a tool to measure students' evaluation of online courses. A second purpose was to examine students' evaluations of our online courses. A principal components analysis revealed six underlying factors that appear to have high validity: appropriateness of readings and assignments; technological tools; instructor feedback and communication; course organization; clarity of outcomes and assignments, and content format. Cronbach's alpha of .98 indicated high inter-item reliability. Feedback from students showed an overall satisfaction with online courses, with somewhat lower satisfaction regarding aspects pertaining to instructor feedback and technology. Students rated content organization and formatting of the content more favorably than other aspects of the course.
\end{abstract}

\section{Introduction}

The purpose of this study was to examine the reliability and validity of a tool to measure students' evaluation of online courses in the School of Education at our university. A second purpose was to describe students' evaluations of online courses in the School of Education.

\section{Best Practice in Online Instruction}

The development and use of online university courses has grown dramatically in the last decade [1], [2]. This growth is a result of several factors which include program marketability, student adaptability and convenience, and the rapid growth of multimedia technology and internet access [2]. In addition, the current students, who have become digital natives, are used to engaging in the use of multiple types of technology and social media. It is extremely important that university faculty in teacher education who teach online courses use research-based practices that increase the achievement of their teacher candidates and model instruction that can be used to engage K-12 students [3].

New teaching models have seen a paradigm shift wherein student control of learning is critical to instruction, but there must be a balance between learner need and what an institution can afford to implement [4]. New emerging technologies and online distance learning have implications for the changing role of the instructor as a partner in learning [4]. Revising current teaching models will assist the needs of the $21^{\text {st }}$ century learner.

The environment of the online course is critical to its success. Students appear to require more immediate feedback from the professor than in a traditional, on campus course such as frequent, written communication regarding threaded discussions, and content [5]. As noted by Bangert [6], students seek prompt feedback specifically related to problems they have when using course management tools and submitting assignments.

Students thrive on faculty who are actively involved in each aspect of the course. Faculty social presence is critical for students to feel engaged, motivated, and effectively engage with peers and their instructor [6]. When faculty establish relationships with the students, are concerned about their learning, and provide opportunities for creating social communities [7], [8]. Moreover, in distance learning environments, "the instructor's role will include not just monitoring and facilitating the interactions, but also actively participating in the exchange of knowledge and reflection. As a partner in learning, both learner and instructor will benefit from the reciprocal learning process [9].

Students need to be provided with engaging, motivating teaching strategies such as structured, fruitful, collaborative asynchronous discussions that promote critical thinking and reflection [10]. The use of multi-media such as wikis, podcasts, audio and visual clips, the presentation software, Prezi, and 
avatars are very effective online learning tools that assist and support teacher candidates and model strategies that can be used in their own teaching [1], [11].

\subsection{Evaluating Online Courses}

Student enrollment in distance learning courses continues to increase in the United States, yet there is concern that students enter these courses without adequate background knowledge or experience in the technological applications necessary for success in online learning environments [12]. In addition, Loveland [13] reports that students have less favorable perceptions of online courses, and current evaluation tools might not address all essential components of online learning. Therefore, we must use caution when interpreting student evaluations of online courses.

In a study by Loveland [13], students' ratings of specific components of online course content were differentially related to various aspects of teaching effectiveness. A significant finding was that organization of course content was critical to a range of measures of teaching effectiveness. However, other components that predicted teaching effectiveness varied, depending on the criterion used to denote effectiveness. Moreover, students appeared to differentiate between instructor behaviors and course organization, suggesting that both components need to be evaluated. Aspects of the course that seemed to indicate teaching effectiveness included timeliness of instructor feedback, instructor interest in student learning, clarity of instructor communication, and the amount learned in the course [13].

Although distance learning is increasingly becoming more common across institutions of higher education, the evaluation of online courses and programs lags behind. Colleges and universities utilize student evaluation of teaching as an indicator of teaching effectiveness, and these evaluations play a large role in tenure and promotion decisions [13]. Institutions have implemented varied approaches to evaluation of distance learning courses, with the responsibility sometimes falling on the course instructor, and in other instances universities have neglected the evaluation of online instruction [14]. Others have attempted to develop a tool, but reliability and validity studies are based on small samples with non-generalizable results [1], [6].

Hathorn and Hathorn [15] stated that they created a valid tool for evaluating online instruction; however, they based their conclusion on findings that both faculty and students rated the survey items similarly. The items on their evaluation tool appear to have face validity and represent domains identified in other research on effective web-based instruction.

\section{Research Questions}

The reliance on student evaluations of teaching when making judgments about teaching effectiveness poses great concern for faculty who teach online courses. As noted above, students tend to rate online courses lower than courses taught face-to-face. Moreover, due to the rapid increase in offering online courses, as well as the continuous changes in platforms and technologies used in distance learning environments, the evaluation of these courses warrants careful consideration. Based upon the research on best practice in online learning, as well as pitfalls with evaluating online instruction, our research examined students' evaluations of online courses, as well as the reliability and validity of the evaluation tool.

\section{Method}

\subsection{Participants}

This study took place in the School of Education at a private university in the northeastern United States. The university offers both undergraduate and graduate programs, with total enrollment of approximately 6,000 students. The School of Education offers more online courses than other Schools on our campus, and it also has two completely online programs.

At our institution, faculty must report scores from student evaluations of instruction in several courses per year as part of the tenure and promotion process. A standardized instrument developed by Educational Testing Services is used, and means are provided by course, with institutional and national means provided for comparison purposes. However, our university has no standard instrument for the evaluation of online courses. Therefore, faculty whose course load consists primarily of online courses might be at a disadvantage when providing course evaluation data for promotion purposes.

Using a survey we developed specifically to evaluate our online courses, data were collected on 281 students (response rate $=64 \%$ ) enrolled in 34 online graduate courses over four semesters (two spring and two fall semesters). These courses ranged 
from beginning special education courses to advanced graduate counseling courses.

\subsection{Instrument}

Beginning in spring 2008, we developed a survey tool based on careful review of the literature on best practice in online learning. This tool was revised several times after faculty and student feedback was gathered. This survey has only been used in the School of Education at our university. The scale consisted of 25 likert type items, using a five point scale $(1=$ strongly disagree; 2 = disagree, 3 = neutral; 4 = agree; 5 = strongly agree) .

\subsection{Procedures}

One of the researchers attended a seminar on best practices for evaluating online instruction. Based upon information presented at the seminar, as well as the literature base on effective online instruction, we created a set of items. After initial creation of the instrument, the researchers piloted the tool with one course, which led to minor revisions of some items. Then we set up the tool on an electronic survey portal, which enabled the collection of anonymous data, as well as the ability to aggregate all responses, and to disaggregate by course and instructor.

Beginning in spring 2009, rosters of all online courses were gathered each semester and entered into the online survey site. At the end of each semester, all enrolled students were invited to participate in the evaluation of their online courses. Students received an email invitation to complete the survey through the secure survey web site. The invitations stated that the purpose of the survey was to gather feedback on their course and that this information was valuable in decisions regarding course and programmatic changes. After one week, follow-up reminder emails were sent to those students who had not yet completed the evaluation. At the end of two weeks, the responses were downloaded and exported into SPSS for analysis. No student identification information was downloaded, thereby ensuring anonymity of responses.

\subsection{Data Analysis}

To determine students' perceptions of their online courses and instructors, item means were calculated for each course and instructor. To examine the reliability of the tool, we calculated a Cronbach's alpha, and we also examined the consistency of ratings for each instructor. A principal components analysis was utilized to determine validity by comparing the factors that emerged to domains identified in the literature base.

\section{Results}

\subsection{Students' Perceptions}

Data were collected on 281 students (response rate = 64\%) across four semesters (spring 2009, fall 2009, spring 2010, and fall 2010). All students completed the 25-item likert survey to examine student evaluation of online courses. The aggregated means indicate a general positive perception of online courses, with means ranging from 3.75 to 4.44 on a $1-5$ scale. As noted in Table 1 below, the items that were rated most positively were primarily those associated with course organization (items 9 and 10) and formatting (items 15 and 20). The data reflected that students rated the following items the lowest: authentic, real-life activies and assignments (item 19), timeliness of instructor instructor feedback (item 5), and technological issues (items 12 and 13). Given a 1-5 rating scale, however, all item scores were above average.

Table 1. Students' perceptions of online courses: survey item means

\begin{tabular}{|l|l|}
\hline Item & Mean \\
\hline $\begin{array}{l}\text { 1. Assignments and activities were clearly } \\
\text { linked to the course objective. }\end{array}$ & 4.44 \\
\hline $\begin{array}{l}\text { 2. Assignments were appropriate and effective } \\
\text { for learning course content. }\end{array}$ & 4.21 \\
\hline 3. Evaluation criteria were clearly stated. & 4.25 \\
\hline $\begin{array}{l}\text { 4. Feedback was informative and clearly } \\
\text { articulated. }\end{array}$ & 4.07 \\
\hline 5. Feedback was delivered in a timely manner. & 3.85 \\
\hline $\begin{array}{l}\text { 6. Evaluation criteria for discussion board } \\
\text { activities were clearly specified in advance. }\end{array}$ & 4.32 \\
\hline $\begin{array}{l}\text { 7. Instructor effectively communicated any } \\
\text { changes/clarified any misunderstanding } \\
\text { regarding course requirements. }\end{array}$ & 4.21 \\
\hline $\begin{array}{l}\text { 8. The sequence of online course activities } \\
\text { was effectively organized and easy to follow. }\end{array}$ & 4.25 \\
\hline $\begin{array}{l}\text { 9. Dates on the syllabus and course schedule } \\
\text { corresponded to online readings. }\end{array}$ & 4.41 \\
\hline $\begin{array}{l}\text { 10. Dates on the course schedule corresponded } \\
\text { to drop box and discussion board submissions. }\end{array}$ & 4.41 \\
\hline $\begin{array}{l}\text { 11. Links were descriptive and provided } \\
\text { information regarding the content. }\end{array}$ & 4.20 \\
\hline
\end{tabular}




\begin{tabular}{|c|c|}
\hline $\begin{array}{l}\text { 12. Links to external readings opened in new } \\
\text { windows. }\end{array}$ & 4.01 \\
\hline $\begin{array}{l}\text { 13. Interactive multimedia items allowed } \\
\text { students to control content. }\end{array}$ & 3.91 \\
\hline $\begin{array}{l}\text { 14. Online course content was consistent in } \\
\text { presentation. }\end{array}$ & 4.31 \\
\hline $\begin{array}{l}\text { 15. Online course materials were free of } \\
\text { spelling errors and grammatical errors. }\end{array}$ & 4.41 \\
\hline $\begin{array}{l}\text { 16. Requirements for drop box submissions } \\
\text { were specified and easy to follow. }\end{array}$ & 4.25 \\
\hline $\begin{array}{l}\text { 17. Discussion board assignments fostered a } \\
\text { high level of interaction among students. }\end{array}$ & 4.04 \\
\hline $\begin{array}{l}\text { 18. Online course content included varied } \\
\text { types of assignments to appeal to different } \\
\text { learning styles. }\end{array}$ & \\
\hline $\begin{array}{l}\text { 19. Online assignments included authentic, } \\
\text { real-life activities. }\end{array}$ & 3.75 \\
\hline $\begin{array}{l}\text { 20. Font size and layout of the online content } \\
\text { was consistent. }\end{array}$ & 4.42 \\
\hline $\begin{array}{lcc}21 . & \text { Technological tools were used } \\
\text { appropriately for the course content. } & \\
\end{array}$ & 4.29 \\
\hline $\begin{array}{l}\text { 22. Technological requirements to complete } \\
\text { the online course were specified. }\end{array}$ & 4.29 \\
\hline $\begin{array}{l}\text { 23. Discussion board activities were designed } \\
\text { to evoke further critical thinking about course } \\
\text { content. }\end{array}$ & 4.28 \\
\hline $\begin{array}{l}\text { 24. Selected readings and resources were } \\
\text { adequate for the course objectives. }\end{array}$ & 4.35 \\
\hline $\begin{array}{l}\text { 25. The course has evoked further interest in } \\
\text { this field. }\end{array}$ & 4.14 \\
\hline
\end{tabular}

\subsection{Reliability and Validity}

To examine the reliability of the instrument, Cronbach's alpha yielded very high inter-item consistency for the online evaluation of faculty survey (alpha $=.98$ ). We then conducted a principal components analysis, with varimax rotation, to determine the factor structure. This analysis revealed a six factor solution, which is described in Table 2.

Table 2. Six underlying domains of the evaluation tool

Factor 1: Appropriateness of Readings and Assignments

1. Assignments were appropriate and effective for learning course content.

2. Discussion board assignments fostered a high level of interaction among students.

3. Online assignments included authentic, reallife activities.

4. Discussion board activities were designed to evoke further critical thinking about course content.
5. Selected readings and resources were adequate for the course objectives.

Factor 2: Technological Tools

1. Links were descriptive and provided information regarding the content.

2. Links to external readings opened in new windows.

3. Interactive multimedia items allowed students to control content.

4. Technological requirements to complete the online course were specified.

5. Technological tools were used appropriately for the course content.

6. Online course content included varied types of assignments to appeal to different learning styles.

Factor 3: Instructor Feedback and Communication

1. Feedback was informative and clearly articulated.

2. Feedback was delivered in a timely manner.

3. Instructor effectively communicated any changes/clarified any misunderstanding regarding course requirements.

Factor 4: Course Organization

1. The sequence of online course activities was effectively organized and easy to follow.

2. Dates on the syllabus and course schedule corresponded to online readings.

3. Dates on the course schedule corresponded to drop box and discussion board submissions.

4. Online course content was consistent in presentation.

Factor 5: Clarity of Outcomes and Requirements

1. Assignments and activities were clearly linked to the course objective.

2. Evaluation criteria were clearly stated.

3. Evaluation criteria for discussion board activities were clearly specified in advance.

4. Requirements for drop box submissions were specified and easy to follow.

5. The course has evoked further interest in this field.

Factor 6: Content Format

1. Online course materials were free of spelling errors and grammatical errors.

2. Font size and layout of the online content was consistent.

\section{Discussion}

The use of student evaluations of teaching remains a critical component in tenure and promotion decisions 
at institutions of higher education. Although there continues to be an increase in online courses offered, institutions have not adequately addressed student evaluations of online instruction. In our School of Education, we have continued to evaluate our online courses, but the evaluation process has undergone many changes due to the lack of standardized instruments or consensus on best practice in online instruction.

Our findings indicate that the evaluation tool reported in this study has high reliability. In addition, the six factors that emerged appear to be related to aspects that need to be included when designing online courses [6], suggesting that the tool might adequately assess aspects of effective practices in online instruction. As noted by Lee and Duncan-Howell [20], key elements for assessing the quality of an online course include accessibility, clear organization of course content, clear expectations, and engaging communication, similar to the six major domains that emerged in our study.

Best practice in online instruction includes providing authentic learning environments where collaborative learning is enhanced through both synchronous and asynchronous discussion platforms [16]. "Dialogue provides not only information about students' learning but is also an important means by which teachers can gain instant feedback about how students learn [17, p. 315]."

Prior research has indicated that students desire a high level of faculty-student interaction in online learning environments [5], [6]. As noted above, students in our online courses reported lower levels of satisfaction with instructor feedback than they rated other aspects of the course, and instructor feedback is a vital component for successful learning in online environments [5], [6].

Students also rated items pertaining to technology (e.g., interactive media, links to external readings, authenticity of online assignments) lower than most other aspects of their online courses. Effective multimedia provides strategies that teacher candidates can also use in their own teaching [1]. Robson [18] has indicated the importance of student-technology interaction and that it has been frequently neglected when designing online learning experiences. Richardson and Turner [19] caution that, "Effective communication is not happening virtually, which is leading to fragmentation of a learning community with feelings of isolation and confusion among some students (p. 2).
The results of this study provide valuable feedback for redesigning specific aspects of our instruction of online courses. Specifically, the selection of technological tools needs to consider student ability to navigate with ease and success. Instructors should provide guidelines to students about technology and resources available for students who experience problems with using technology [6]. Furthermore, the courses must include more authentic experiences to engage students, one of the seven principles of effective on line teaching identified by Bangert [6].

Finally, one of the most crucial aspects of online learning is the faculty-student interaction; student learning is enhanced when faculty connect with students throughout the entire learning process and demonstrate an interest in their learning [7], [8]. Perhaps our School of Education should specify specific guidelines for minimal levels of facultystudent interaction, including feedback on assignments, as well as a framework that includes best practiced based on research and student input.

\section{References}

[1] A.P. Rovai, M.K. Ponton, and J.D. Baker, Distance Learning in Higher Education, Teachers College Press, New York, USA, 2008.

[2] D. Sprague, C. Maddux, R. Ferdig, and P. Albion, "Online Education: Issues and Research Questions", Journal of Technology and Teacher Education, Association for the Advancement of Computing in Education, Chesapeake, Virginia, USA, 2007, pp. 157-166.

[3] H.E. Duncan, and J. Barnett, "Learning to Teach Online: What Works for Pre-service Teachers", Journal of Educational Computing Research, Baywood Publishing, New York, USA, 2009, pp. 357-376.

[4] Y. Balderrain, "Distance Education Trends: Integrating New Technologies to Foster Student Interaction and Collaboration”, Distance Education, Routledge, Orlando, FL, 2006, pp. 139-153.

[5] S. Young, "Student Views of Effective Online Teaching in Higher Education", The American Journal of Distance Education, Lawrence Erlbaum Associates, New Jersey, USA, 2006, pp.65-77.

[6] A.W. Bangert, "The Seven Principles of Good Practice: A Framework for Evaluating Online Teaching”, Internet and Higher Education, Elsevier, Cambridge, MA, 2004, pp. 217-232. 
[7] J.E. Cole, and J.B. Kritzer, "Strategies for Success: Teaching an Online Course”, Rural Special Education Quarterly, ACRES, Illinois, USA, 2009, pp. 36-40.

[8] B. Perry, J. Dalton, and M. Edwards, "Photographic Images as an Interactive Online Teaching Technology: Creating Online Communities", International Journal of Teaching and Learning in Higher Education, Virginia, USA, 2009, pp. 106-115.

[9] G. Kearsley, and B. Shneiderman. "Engagement Theory: A Framework for Technology-Based Teaching and Learning”, Retrieved July 27, 2011, from http://home.sprynet.com/ gkearsley/engage.htm.

[10] A.P. Rovai, "Facilitating Online Discussions Effectively", Internet and Higher Education", Elsevier, London, England, 2007, pp. 77-88.

[11] P. Lam, and C. McNaught, "Design and Evaluation of Online Courses Containing Media-enhanced Learning Materials”, Educational Media International, Routledge, London, England, 2006, pp. 199-218.

[12] J. P. Lorenzetti, "Lessons Learned about Student Issues in Online Learning”, Distance Education Report, Magna Publications, Madison, WI, USA, 2005, pp. 4-5.

[13] K. Loveland, "Student Evaluation of Teaching (SET) in Web-Based Classes: Preliminary Findings and a Call for Further Research”, Journal of Educators Online, 2007, pp. 1-18, Retrieved July 30, 2011, from http://www.eric.ed.gov/PDFS/EJ907746.pdf.

[14] D. Compora, "Current Trends in Distance Education: An Administrative Model”, Online

Journal of Distance Learning Administration, State University of West Georgia, Carrolltown, GA, 2003, Retrieved September 27, 2010, from

http://www.westga.edu/ distance/ojdla/summer62/compora6 2.html.

[15] L. Hathorn, and J. Hathorn, "Evaluation of Online Course Websites: Is Teaching Online a Tug-of-War?”, Journal of Educational Computing Research,

Baywood Publishing, Amityville, NY, 2010, pp. 197-217.

[16] K. Lee, and J. Duncan-Howell, "How Do We Know ELearning Works? Or Does It?”, E-Learning and Digital Media, Symposium Journals Ltd, Oxford, UK, 2007, pp. 482-496.

[17] K. Tirri, and A. Nevgi. "In Search of a Good Virtual Teacher", Paper presented at the Annual European Conference on Educational Research, Edinburgh, UK.

[18] E. Lofstrom, and A. Nevgi. "From Strategic Planning to Meaningful Learning: Diverse Perspectives on the Development of Web-Based Teaching and Learning in
Higher Education". British Journal of Educational Technology, Blackwell Publishing, Oxford, UK, 2006, pp. 312-324.

[19] J. Robson, "Evaluating Online Teaching", Open Learning, Taylor \& Francis, London, England, 2001, pp. 151- 172

[20] J.A. Richardson, and A.Turner, "Collaborative "Learning in the Virtual Classroom: Lessons Learned and a New Set of Tutor Guidelines”, The National Teaching and Learning Forum, Taylor \& Francis, London, England, 2001, pp. 1-4. 